\title{
High MET gene copy number predicted poor prognosis in primary intestinal diffuse large B-cell lymphoma
}

\author{
Wan-Ting Huang ${ }^{1}$ and Shih-Sung Chuang ${ }^{2^{*}}$
}

\begin{abstract}
Background: MET is a proto-oncogene with its copy number $(C N)$ alterations been reported in some cancers, but not in primary intestinal diffuse large B-cell lymphoma (PI-DLBL) yet.

Methods: In this retrospective study, we performed histology and chart reviews, immunohistochemistry and quantitative polymerase chain reaction for MET CN alterations on 28 surgically resected PI-DLBLs.

Results: There were 12 men and 16 women with a median age of 70 and a mean follow-up of 32 months. The median MET CN was 2.20 (range, 1.04 to 3.35). CN gain was observed in 11 cases, including 5 with CN greater than 3. Nine patients (32\%) had diploid CN and eight (29\%) with CN loss. Patients with gain or diploid CN showed significantly worse prognosis $(P=0.046)$ than those with $C N$ loss. Furthermore, MET CN greater than 3 was associated with an adverse outcome $(P=0.003)$. Intestinal perforation at presentation was the sole clinicopathological factor associated with a poor prognosis $(P=0.004)$ and perforation was correlated with $C N$ greater than $3(P=0.002)$.
\end{abstract}

Conclusions: Our finding of MET CN gain as a poor prognostic factor in PI-DLBL patients might serve as the rationale for targeting MET signaling pathway in the treatment of these patients.

Keywords: Copy number, Diffuse large B-cell lymphoma, Intestine, MET, Primary intestinal diffuse large B-cell lymphoma, Taiwan

\section{Background}

Copy number alterations (CNAs) of genes are indications of genomic instability that are common in cancers and have been known to be associated with the development of malignancy [1,2]. CNAs of specific genes may deregulate signal pathways that enhance the proliferation and inhibit the apoptosis of tumor cells. Cumulative evidences suggest a link between CNAs and prognosis of cancer patients [3]. CNAs of particular genes may provide insights into the pathogenesis of certain neoplasms and the clues for target therapy. Hepatocyte growth factor (HGF)/MET pathway is one of the most commonly activated signaling pathways in human malignancies. Deregulated HGF/MET signaling axis contributes to

\footnotetext{
* Correspondence: cmh5301@mail.chimei.org.tw

${ }^{2}$ Department of Pathology, Chi-Mei Medical Center, Tainan, Taipei Medical University and National Taiwan University Hospital, Taipei, Taiwan

Full list of author information is available at the end of the article
}

tumorigenesis and invasion/metastasis by the following cellular behaviors collectively described as invasive growth: proliferation and survival (resistance to apoptotic signals), increased cell motility, cell dissociation (scattering), epithelial tubulogenesis, infiltration of tissues, and stimulation of angiogenesis [4-6]. The HGF/ MET pathway may be activated by mutations or genomic amplification of the $M E T$ gene and ligandindependent kinase activation by extracellular proteins, autocrine overexpression of HGF ligand, and increased expression of HGF activator [6,7]. Recent studies have provided important evidence for $M E T$ CNAs in gastric cancer and non-small cell lung cancer (NSCLC) [8-10]. Although some studies have shown that HGF/MET pathway might be implicated in B-cell neoplasms particularly diffuse large B-cell lymphoma (DLBL) and multiple myeloma (MM) [11-18], it is still an unresolved

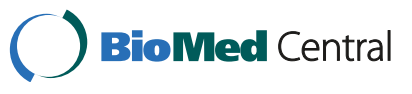


issue for the impact of $M E T$ CNA in the survival of patients with these hematological malignancies.

In a previous study, we identified perforation as the sole clinicopathological prognostic factor in patients with primary intestinal DLBL (PI-DLBL) [19]. In this current retrospective study we investigated the prognostic impact of MET CNAs by quantitative polymerase chain reaction (qPCR) method and found that in addition to perforation, MET CNAs were also significantly associated with prognosis.

\section{Materials and methods}

\section{Case selections and clinical data}

Strict inclusion and diagnostic criteria for PI-DLBL were applied as previously reported [19]. Medical records were reviewed and overall survival was measured from the date of diagnosis to the date of last follow-up. Chi-Mei Institutional Review Board approved this study.

\section{DNA extraction}

To avoid the contamination by normal cells, we reviewed the HE sections of each case and chose those containing greater than $90 \%$ tumor cells without or with only minimal tumor necrosis for DNA extraction. Three to five $10 \mu \mathrm{m}$ thick paraffin sections of each case were cut into an eppendorf tube from a representative block with disposable blades. The paraffin rolls were deparaffinized with xylene followed by three washings with ethanol. Paraffin-free tissue was dried in a heating box for $15 \mathrm{~min}$ at $37^{\circ} \mathrm{C}$ and then subjected to the DNA extraction procedures using QIAamp DNA mini kit (Qiagen, Hilden, Germany). The quality and DNA concentration were measured by NanoPhotometer (IMPLEN, München, Germany). DNA with 260/280 ratios of 1.6-2.0 with a minimal concentration of $25 \mathrm{ng} / \mu \mathrm{l}$ DNA were required for qPCR assay.

\section{Copy number assay}

We performed qPCR assay to determine the CNAs of $M E T$ gene by using the commercially available 6carboxy-fluorescine (FAM)-labeled MET probe (Applied Biosystems assay ID no. Hs02764674, Applied Biosystems, Foster City, CA). Ribonuclease P (RNase P), which is known to exist in two copies, was used as the endogenous control with 4,7,2-trichloro-7-phenyl-6-carboxyfluorescein (VIC)-labeled probe (Applied Biosystems Part no. 4403326). The peripheral blood mononuclear cells from six healthy individuals served as control samples. Each experiment was performed using a 96-well optical PCR plate and the StepOnePlus real-time PCR machine (Applied Biosystems) with default cycling conditions. According to manufacturer's instruction, a total of $10 \mathrm{ng}$ of genomic DNA was added to the PCR reaction mixture containing 1× final concentration TaqMan Gene Expression PCR
Master Mix (Applied Biosystems) and 1x final predesigned primer/probe Mix (Applied Biosystems) in a final volume of $10 \mu \mathrm{L}$. Each sample was run in triplicate. After amplification, the Ct values for both target and reference genes were imported into the CopyCaller Software (Applied Biosystems) for data analysis. The $\mathrm{CN}$ of the target gene was determined by comparative quantitative threshold cycle $(\Delta \Delta \mathrm{Ct})$ method where $\Delta \Delta \mathrm{Ct}=(\mathrm{Ct}$ of target gene, test sample - Ct of RNase P, test sample) (average $\mathrm{Ct}$ of target gene, reference samples - average $\mathrm{Ct}$ of RNase P, reference samples) and then using the formula $2 \times 2^{-\Delta \Delta C t}$ [20]. The cutoff value of target genes was set at 3 standard deviation of the mean derived from the six normal control samples. Each sample was then assigned to have diploid $M E T C N$, gain, or loss.

\section{Statistical analysis}

The associations between $M E T \mathrm{CN}$ and various clinical and immunophenotypical parameters were assessed by $x^{2}$ test or Fisher's exact test. Kaplan-Meier survival curves were drawn and the log rank test was used to compare the differences between survival curves. All statistical analyses were performed using SPSS for windows 11.0 software (SPSS Inc. Chicago, IL). A $P$ value of 0.05 or less was considered statistically significant.

\section{Results}

These 28 patients included 12 males and 16 females with a median age of 70 years (range, 26 to 88 ). Six patients (21\%) presented with intestinal perforation. The staging results were available in 27 patients including $9(33 \%)$ at stage IE, 14 (52\%) at stage IIE and $4(15 \%)$ at stage IVE. Nineteen patients $(70 \%)$ received chemotherapy with cyclophosphamide, doxorubicin, vincristine, and prednisolone (CHOP) or similar regimens. Among these, 12 patients received combined Rituximab therapy and others additional radiotherapy. Eight patients (30\%) received only supportive treatment without chemo- or radiotherapy due to poor general condition. The mean follow-up time was 32 months (range, 0.3 to 110). The overall 1-, 2- and 5-year survival rates were 50, 43 and $18 \%$, respectively. Immunohistochemically, 22 tumors (79\%) expressed bcl-2, bcl-6 and MUM1/IRF4; while only 6 tumors (21\%) expressed CD10. Nineteen tumors (68\%) had concurrent expression of bcl-2 and MUM1. All tumors were negative for cyclin D1. Seven tumors (25\%) were classified as germinal centre B-cell (GCB) phenotype and 21 non-GCB (75\%) according to the algorithm of Hans et al. [21]. Patients with intestinal perforation at presentation showed a poor prognosis compared to those without $(P=0.004$; Figure 1$)$. The other clinicopathological or immunohistochemical findings including all differentiation markers and GCB vs. non-GCB phenotype were of no prognostic significance. 


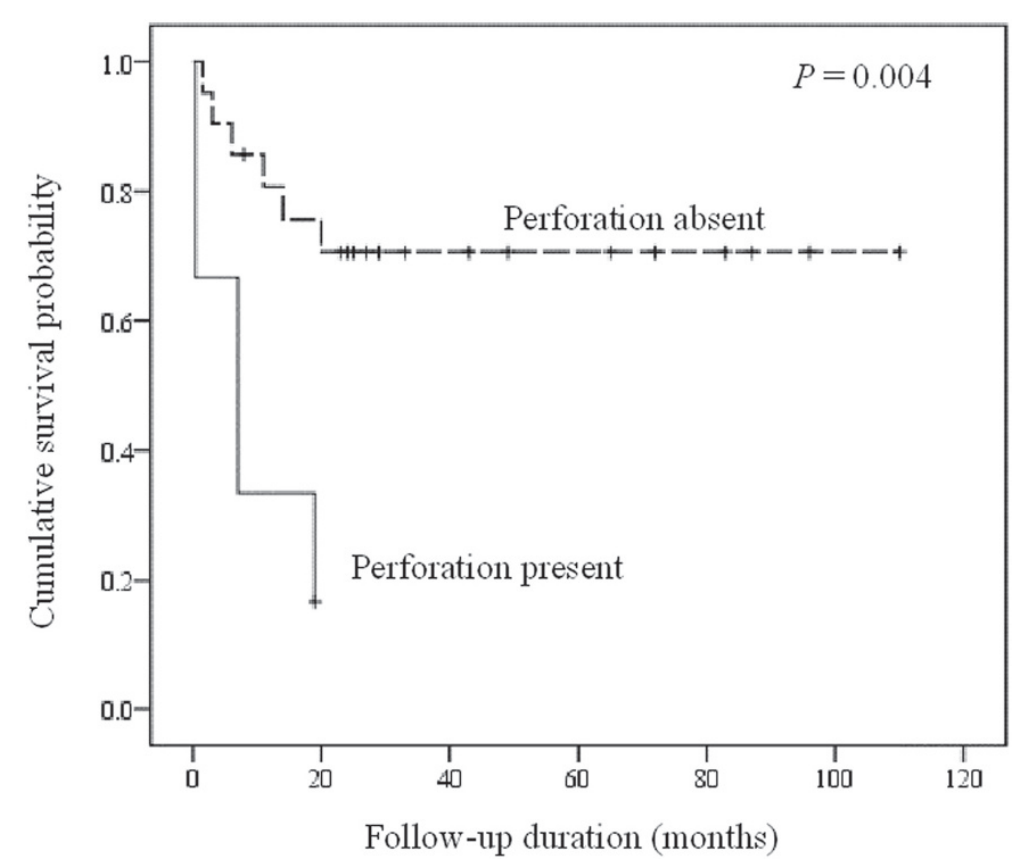

Figure 1 Cumulative survival shows a significantly poorer outcome in patients presented with perforation.

Table 1 summarizes the associations between MET CN and the clinicopathologic features. Of these 28 cases the median MET CN was 2.20 (range, 1.04 to 3.35; Figure 2). Deriving from the results of normal control specimens, the tumors with a cut-off value of greater than 2.35 copies was designated as having $M E T C N$ gain, and those with less than 1.77 as $\mathrm{CN}$ loss. According to these criteria, 11 patients (39\%) had MET CN gain (median: 2.94 copies; range, 2.48 to 3.35 ), 8 (29\%) with $\mathrm{CN}$ loss (median: 1.33; range, 1.04 to 1.66$)$, and 9 (32\%) with normal/diploid $\mathrm{CN}$ (median: 2.00; range, 1.91 to 2.28). Patients with $M E T C N$ gain or normal/diploid $M E T \mathrm{CN}$ showed a significant worse prognosis than those with $M E T C N$ loss $(P=0.046$; Figure 3). We also found that the patients with $M E T \mathrm{CN}$ gain of greater than 3 copies showed a poorer prognosis as compared to those with $\mathrm{CN}$ of less than $3(P=0.003$; Figure 4). There was also a significant correlation between $M E T \mathrm{CN}$ gain of greater than 3 copies and perforation at disease presentation $(P=0.002)$.

\section{Discussion}

In this study, we investigated the prognostic role of the $M E T$ CNAs in surgically resected PI-DLBL and found that tumors with $M E T \mathrm{CN}$ gain greater than 3 copies were associated with an unfavorable prognosis and also with perforation at disease presentation. Normal or lower level MET CN gain also denoted a trend toward poor prognosis, although the statistical significance was low. We speculate that the clinical impact of $M E T C N$ on prognosis might be amplification dosage dependent.
Table 1 Correlation between MET copy number and parameters

\begin{tabular}{|c|c|c|c|c|c|}
\hline & \multirow[b]{2}{*}{ Case no. (\%) } & \multicolumn{4}{|c|}{ MET copy number } \\
\hline & & $>3$ copies $(\%)$ & $P$ & Loss (\%) & $P$ \\
\hline \multicolumn{6}{|l|}{ Gender } \\
\hline Male & $12(43)$ & $2(40)$ & 0.89 & $3(38)$ & 0.72 \\
\hline Female & $16(57)$ & $3(60)$ & & $5(62)$ & \\
\hline \multicolumn{6}{|c|}{ Age (years) } \\
\hline$\geq 60$ & $8(29)$ & $1(20)$ & 0.65 & $2(25)$ & 0.8 \\
\hline$<60$ & $20(71)$ & $4(80)$ & & $6(75)$ & \\
\hline \multicolumn{6}{|c|}{ B symptom } \\
\hline Present & $6(22)$ & $1(20)$ & 0.9 & $0(0)$ & 0.08 \\
\hline Absent & $21(78)$ & $4(80)$ & & $8(100)$ & \\
\hline \multicolumn{6}{|c|}{ Perforation } \\
\hline Present & $6(21)$ & $3(60)$ & 0.02 & $1(13)$ & 0.48 \\
\hline Absent & $22(79)$ & $2(40)$ & & $7(87)$ & \\
\hline \multicolumn{6}{|c|}{ Ann Arbor stage } \\
\hline | or || & $23(85)$ & $5(100)$ & 0.31 & $7(87)$ & 0.83 \\
\hline III or IV & $4(15)$ & $0(0)$ & & $1(13)$ & \\
\hline \multicolumn{6}{|c|}{ Immunophenotype } \\
\hline GCB & $7(25)$ & $1(20)$ & 0.78 & $3(38)$ & 0.34 \\
\hline Non-GCB & $21(75)$ & $4(80)$ & & $5(62)$ & \\
\hline
\end{tabular}




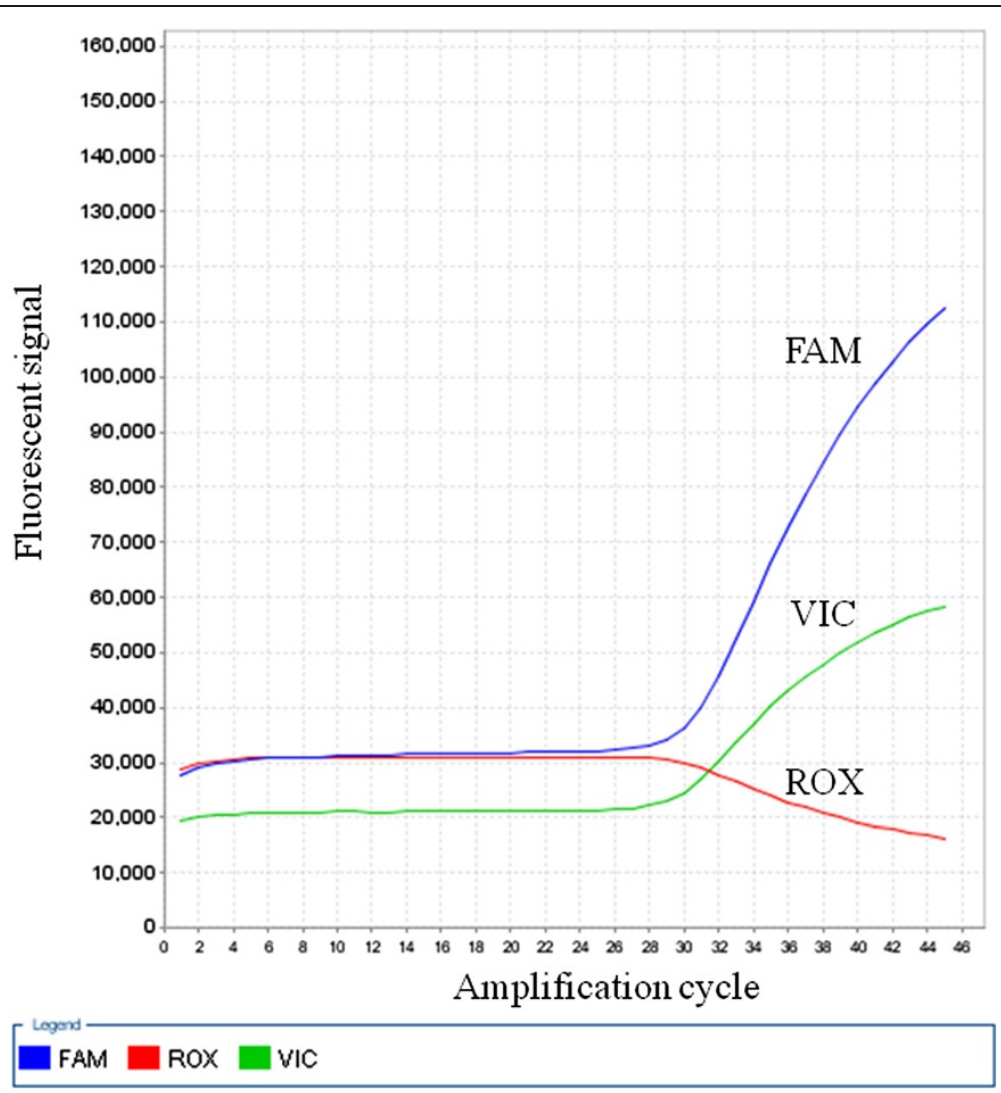

Figure 2 A representative case with MET copy number data analyzed by CopyCaller Software showing increased FAM to VIC ratio, indicating increased CN. Abbreviations: FAM, 6-carboxy-fluorescine-labeled MET probe; ROX (carboxy-X-rhodamine), internal reference dye used for normalization of fluorescent signal variations between wells; VIC: 4,7,2-trichloro-7-phenyl-6-carboxyfluorescein-labeled RNase $P$ probe.

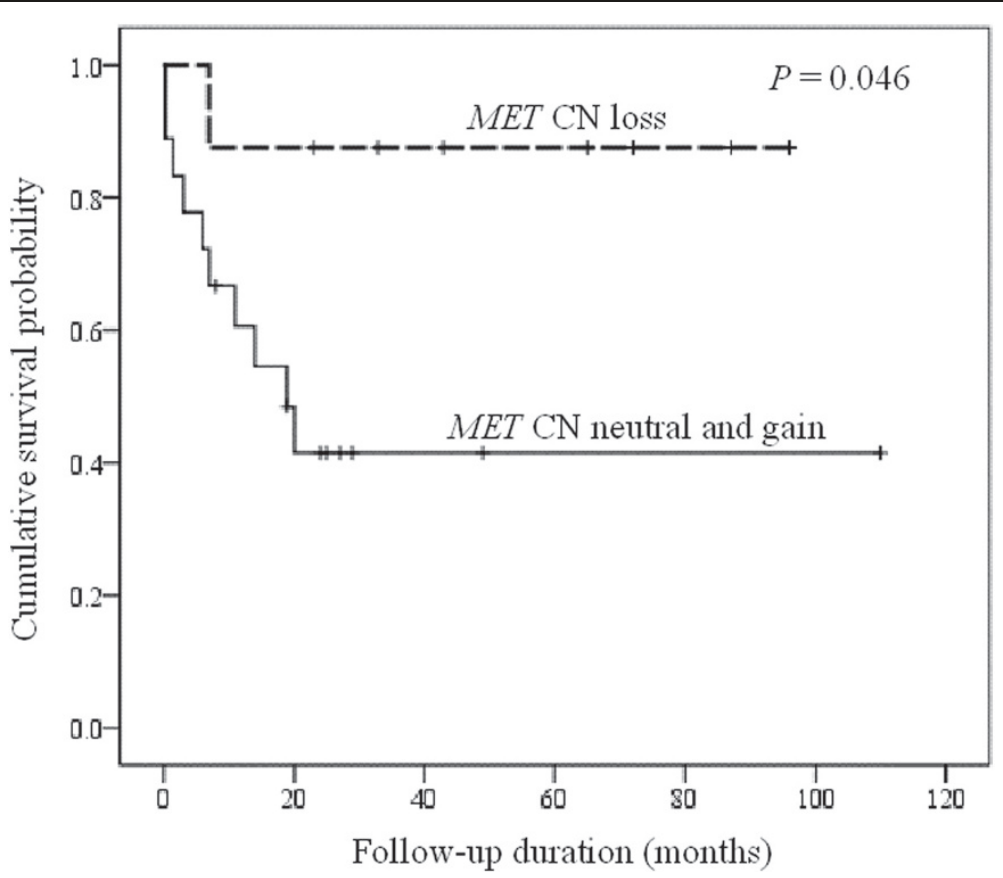

Figure 3 Cumulative survival shows a significantly poorer outcome in patients with diploid or gain of MET CN than those with CN loss. 


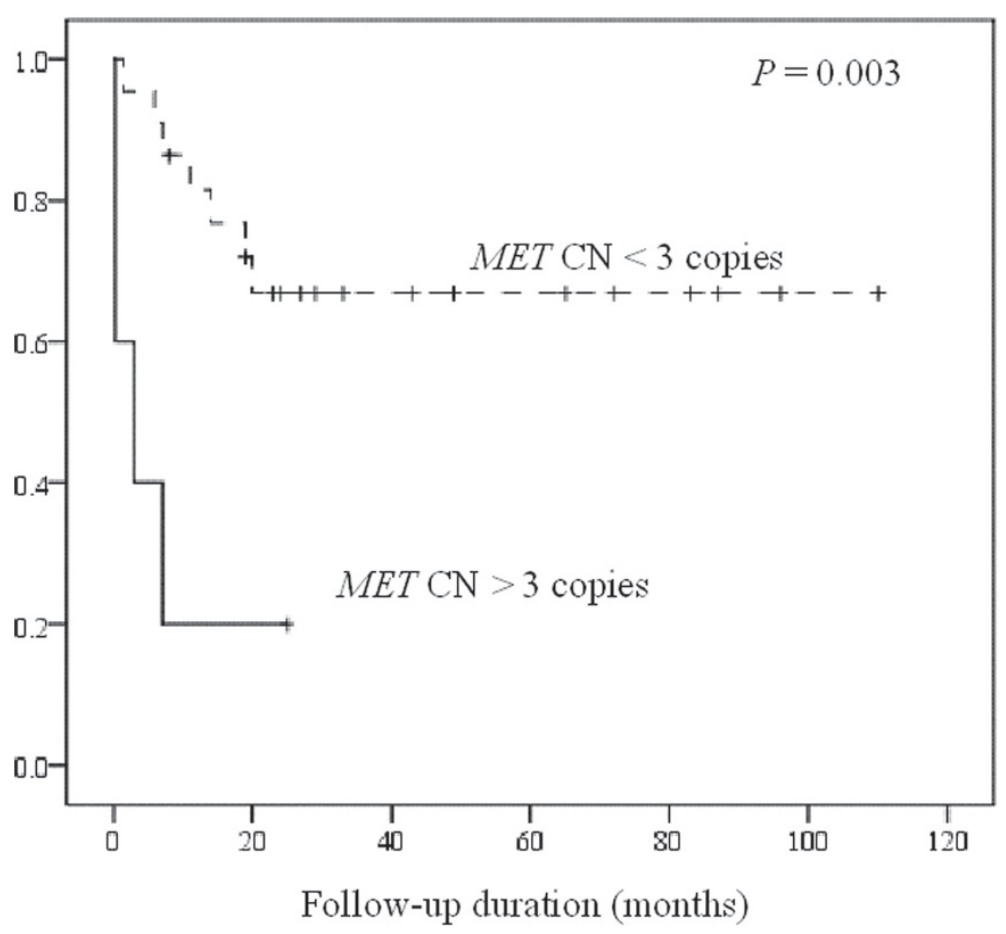

Figure 4 Cumulative survival shows a significantly poorer outcome in patients with $M E T C N>3$ copies than those with CN $<3$ copies.

Furthermore, we re-confirmed our previous findings that tumor perforation was a poor prognostic factor in PIDLBL and that the relative frequency of GCB phenotype was low in PI-DLBL, although the latter was not significantly related to prognosis [19].

HGF/MET pathway could be activated in both benign and malignant B-cells. Amplification of the MET gene would result in MET protein over-expression and constitutive kinase activation [22]. MET CNAs have been investigated in solid cancer such as gastric carcinoma and NSCLC [8-10]. Depending on the methods for assessing MET CNAs, MET amplification has been identified in $4-21 \%$ of gastric carcinomas [23,24]. An increase of MET CN was associated with higher tumor stage at presentation and poorer survival in patients with gastric cancer [10,25]. For a subset of lung cancers with acquired resistance to epidermal growth factor receptortargeting therapy, MET amplification is one of the most frequently involved mechanisms [26]. In NSCLC, MET gene has been shown to be amplified in $21-24 \%$ of tumors and the impact of $M E T \mathrm{CN}$ on prognosis is histological subtype dependent: $M E T$ amplification with a poorer prognosis in patients with adenocarcinoma but not in those with squamous cell carcinoma [9,27].

Among the various entities of non-Hodgkin lymphomas, MET is frequently over-expressed in DLBL $[14,15,17]$. Over-expression of HGF/MET signaling activates downstream molecules that control proliferation, adhesion and apoptosis. In the literature, however, the prognostic significance of MET over-expression in DLBL is controversial. High serum HGF levels and overactive HGF/MET pathway in DLBL patients have been reported to be linked with unfavorable outcome in several studies $[14,28,29]$. On the other hand, Uddin et al. showed a better overall survival at 5 years in DLBL patients with MET over-expression than those with low MET expression level (76.2\% vs. $57.5 \% ; P=0.0025$ ) [13]. A study from the Middle East also showed that MET over-expression carried a better prognosis in DLBL patients [13]. So far MET gene $\mathrm{CN}$ has not been investigated in malignant lymphoma yet. To the best of our knowledge, our study is the first report describing the prognostic significance of MET CNAs in patients with PI-DLBL. Our results suggested that higher $M E T \mathrm{CN}$, possibly leading to MET over-expression, might be a poor prognostic indicator for PI-DLBL.

High serum HGF levels have been found in patients with DLBL and MM, and they were associated with an unfavorable prognosis [14,30-32]. Furthermore, tumor cells could up-regulate HGF production, through paracrine and/or autocrine mechanisms, by the surrounding stromal cells or cancer cells themselves [7,33]. With the recent development of clinical-grade agents targeting the HGF/MET pathway, inhibition of this pathway is currently considered a rational and promising strategy for the treatment of patients with B-cell lymphoma and MM [13,34]. Among these agents, Crizotinib (PF-02341066) is an orally bioavailable, ATP-competitive, small-molecule inhibitor of c-MET and anaplastic lymphoma kinase, and is considered 
a very potential agent for treatment of cancers dependent on these oncogenic kinases for growth and survival [35,36]. Our results of high MET CN gain in PI-DLBL patients with poor prognosis suggested that blocking HGF/MET pathway might be a promising adjuvant therapeutic option.

\section{Abbreviations}

CN: Copy number; PI-DLBL: Primary intestinal diffuse large B-cell lymphoma; CNA: Copy number alteration; HGF: Hepatocyte growth factor; NSCLC: Nonsmall cell lung cancer; DLBL: Diffuse large B-cell lymphoma; MM: Multiple myeloma.

\section{Competing interests}

The authors declare that they have no competing interests.

\section{Authors' contributions}

WTH did the experiment, analyzed the data and drafted the manuscript. SSC conceived and coordinated the study, analyzed the data and wrote the manuscript. Both authors read and approved the final manuscript.

\section{Acknowledgments}

The work was supported by research grants from Chang Gang Medical Center, Kaohsiung (grant no. CMRPG880172 to W.-T.H.), Chi-Mei Medical Center, Tainan (grant no. CMFHR100004 to S.-S.C.), and National Science Council, Taipei, Taiwan (grant no. NSC 101-2314-B-384-006 to S.-S.C.).

\section{Author details}

${ }^{1}$ Department of Pathology, Kaohsiung Chang Gung Memorial Hospital and Chang Gung University College of Medicine, Kaohsiung, Taiwan.

${ }^{2}$ Department of Pathology, Chi-Mei Medical Center, Tainan, Taipei Medical University and National Taiwan University Hospital, Taipei, Taiwan.

Received: 17 January 2013 Accepted: 31 January 2013

Published: 4 February 2013

\section{References}

1. Stuart D, Sellers WR: Linking somatic genetic alterations in cancer to therapeutics. Curr Opin Cell Biol 2009, 21:304-310.

2. Baudis M: Genomic imbalances in $\mathbf{5 9 1 8}$ malignant epithelial tumors: an explorative meta-analysis of chromosomal CGH data. BMC Cancer 2007, 7:226.

3. Beroukhim R, Mermel CH, Porter D, Wei G, Raychaudhuri S, Donovan J, Barretina J, Boehm JS, Dobson J, Urashima M, Mc Henry KT, Pinchback RM, Ligon AH, Cho YJ, Haery L, Greulich H, Reich M, Winckler W, Lawrence MS, Weir BA, Tanaka KE, Chiang DY, Bass AJ, Loo A, Hoffman C, Prensner J, Liefeld T, Gao Q, Yecies D, Signoretti S, et al: The landscape of somatic copy-number alteration across human cancers. Nature 2010, 463:899-905.

4. Peschard P, Park M: From Tpr-Met to Met, tumorigenesis and tubes. Oncogene 2007, 26:1276-1285.

5. Cecchi F, Rabe DC, Bottaro DP: Targeting the HGF/Met signalling pathway in cancer. Eur J Cancer 2010, 46:1260-1270.

6. Appleman LJ: MET signaling pathway: a rational target for cancer therapy. J Clin Oncol 2011, 29:4837-4838.

7. Birchmeier C, Birchmeier W, Gherardi E, Vande Woude GF: Met, metastasis, motility and more. Nat Rev Mol Cell Biol 2003, 4:915-925.

8. Cappuzzo F, Marchetti A, Skokan M, Rossi E, Gajapathy S, Felicioni L, Del Grammastro M, Sciarrotta MG, Buttitta F, Incarbone M, Toschi L, Finocchiaro G, Destro A, Terracciano L, Roncalli M, Alloisio M, Santoro A, Varella-Garcia $M$ : Increased MET gene copy number negatively affects survival of surgically resected non-small-cell lung cancer patients. J Clin Oncol 2009, 27:1667-1674.

9. Beau-Faller M, Ruppert AM, Voegeli AC, Neuville A, Meyer N, Guerin E, Legrain M, Mennecier B, Wihlm JM, Massard G, Quoix E, Oudet P, Gaub MP: MET gene copy number in non-small cell lung cancer: molecular analysis in a targeted tyrosine kinase inhibitor naive cohort. J Thorac Oncol 2008, 3:331-339.

10. Graziano F, Galluccio N, Lorenzini P, Ruzzo A, Canestrari E, D'Emidio S, Catalano V, Sisti V, Ligorio C, Andreoni F, Rulli E, Di Oto E, Fiorentini G, Zingaretti C, De Nictolis M, Cappuzzo F, Magnani M: Genetic Activation of the MET Pathway and Prognosis of Patients With High-Risk, Radically Resected Gastric Cancer. J Clin Oncol 2011, 29:4789-4795.

11. Uddin S, Hussain AR, Ahmed M, Bu R, Ahmed SO, Ajarim D, Al-Dayel F, Bavi $P$, Al-Kuraya KS: Inhibition of fatty acid synthase suppresses c-Met receptor kinase and induces apoptosis in diffuse large B-cell lymphoma. Mol Cancer Ther 2010, 9:1244-1255.

12. Derksen PW, de Gorter DJ, Meijer HP, Bende RJ, van Dijk M, Lokhorst HM, Bloem AC, Spaargaren M, Pals ST: The hepatocyte growth factor/Met pathway controls proliferation and apoptosis in multiple myeloma. Leukemia 2003, 17:764-774.

13. Uddin S, Hussain AR, Ahmed M, Al-Dayel F, Bu R, Bavi P, Al-Kuraya KS: Inhibition of C-MET is a potential therapeutic strategy for treatment of diffuse large B-cell lymphoma. Lab Invest 2010, 90:1346-1356.

14. Kawano R, Ohshima K, Karube K, Yamaguchi T, Kohno S, Suzumiya J, Kikuchi $\mathrm{M}$, Tamura K: Prognostic significance of hepatocyte growth factor and cMET expression in patients with diffuse large B-cell lymphoma. $\mathrm{Br} J$ Haematol 2004, 127:305-307.

15. Tjin EP, Groen RW, Vogelzang I, Derksen PW, Klok MD, Meijer HP, van Eeden S, Pals ST, Spaargaren M: Functional analysis of HGF/MET signaling and aberrant HGF-activator expression in diffuse large B-cell lymphoma. Blood 2006, 107:760-768.

16. Borset M, Hjorth-Hansen H, Seidel C, Sundan A, Waage A: Hepatocyte growth factor and its receptor c-met in multiple myeloma. Blood 1996, 88:3998-4004

17. Capello D, Gaidano G, Gallicchio M, Gloghini A, Medico E, Vivenza D, Buonaiuto D, Fassone L, Avanzi GC, Saglio G, Prat M, Carbone A: The tyrosine kinase receptor met and its ligand HGF are co-expressed and functionally active in HHV-8 positive primary effusion lymphoma. Leukemia 2000, 14:285-291.

18. Mahadevan D, Spier C, K DC, Miller S, George B, Riley C, Warner S, Grogan TM, Miller TP: Transcript profiling in peripheral T-cell lymphoma, not otherwise specified, and diffuse large B-cell lymphoma identifies distinct tumor profile signatures. Mol Cancer Ther 2005, 4:1867-1879.

19. Chuang SS, Ye H, Yang SF, Huang WT, Chen HK, Hsieh PP, Hwang WS, Chang KY, Lu CL, Du MQ: Perforation predicts poor prognosis in patients with primary intestinal diffuse large B-cell lymphoma. Histopathology 2008, 53:432-440.

20. Li LH, Ho SF, Chen CH, Wei CY, Wong WC, Li LY, Hung SI, Chung WH, Pan WH, Lee MT, Tsai FJ, Chang CF, Wu JY, Chen YT: Long contiguous stretches of homozygosity in the human genome. Hum Mutat 2006, 27:1115-1121.

21. Hans CP, Weisenburger DD, Greiner TC, Gascoyne RD, Delabie J, Ott G, Muller-Hermelink HK, Campo E, Braziel RM, Jaffe ES, Pan Z, Farinha P, Smith LM, Falini B, Banham AH, Rosenwald A, Staudt LM, Connors JM, Armitage JO, Chan WC: Confirmation of the molecular classification of diffuse large B-cell lymphoma by immunohistochemistry using a tissue microarray. Blood 2004, 103:275-282.

22. Comoglio PM, Giordano S, Trusolino L: Drug development of MET inhibitors: targeting oncogene addiction and expedience. Nat Rev Drug Discov 2008, 7:504-16.

23. Tsugawa K, Yonemura Y, Hirono Y, Fushida S, Kaji M, Miwa K, Miyazaki I, Yamamoto H: Amplification of the c-met, c-erbB-2 and epidermal growth factor receptor gene in human gastric cancers: correlation to clinical features. Oncology 1998, 55:475-481.

24. Lee J, Seo JW, Jun HJ, Ki CS, Park SH, Park YS, Lim HY, Choi MG, Bae JM, Sohn TS, Noh JH, Kim S, Jang HL, Kim JY, Kim KM, Kang WK, Park JO: Impact of MET amplification on gastric cancer: possible roles as a novel prognostic marker and a potential therapeutic target. Oncol Rep 2011, 25:1517-1524

25. Lennerz JK, Kwak EL, Ackerman A, Michael M, Fox SB, Bergethon K, Lauwers GY, Christensen JG, Wilner KD, Haber DA, Salgia R, Bang YJ, Clark JW, Solomon BJ, lafrate AJ: MET Amplification Identifies a Small and Aggressive Subgroup of Esophagogastric Adenocarcinoma With Evidence of Responsiveness to Crizotinib. J Clin Oncol 2011, 29:4803-4810.

26. Engelman JA, Zejnullahu K, Mitsudomi T, Song Y, Hyland C, Park JO, Lindeman N, Gale CM, Zhao X, Christensen J, Kosaka T, Holmes AJ, Rogers AM, Cappuzzo F, Mok T, Lee C, Johnson BE, Cantley LC, Jänne PA: MET amplification leads to gefitinib resistance in lung cancer by activating ERBB3 signaling. Science 2007, 316:1039-1043.

27. Shibata T, Uryu S, Kokubu A, Hosoda F, Ohki M, Sakiyama T, Matsuno Y, Tsuchiya R, Kanai Y, Kondo T, Imoto I, Inazawa J, Hirohashi S: Genetic classification of lung adenocarcinoma based on array-based comparative 
genomic hybridization analysis: its association with clinicopathologic features. Clin Cancer Res 2005, 11:6177-6185.

28. Hsiao LT, Lin JT, Yu IT, Chiou TJ, Liu JH, Yen CC, Wang WS, Chen PM: High serum hepatocyte growth factor level in patients with non-Hodgkin's lymphoma. Eur J Haematol 2003, 70:282-289.

29. Giles FJ, Vose JM, Do KA, Johnson MM, Manshouri T, Bociek G, Bierman PJ, O'Brien SM, Kantarjian HM, Armitage JO, Albitar M: Clinical relevance of circulating angiogenic factors in patients with non-Hodgkin's lymphoma or Hodgkin's lymphoma. Leuk Res 2004, 28:595-604.

30. Seidel C, Lenhoff S, Brabrand S, Anderson G, Standal T, Lanng-Nielsen J, Turesson I, Borset M, Waage A: Hepatocyte growth factor in myeloma patients treated with high-dose chemotherapy. Br J Haematol 2002, 119:672-676.

31. Ludek P, Hana S, Zdenek A, Martina A, Dana K, Tomas B, Lucie K, Marta K, Jaroslav M, Miroslav P, Jiri V, Roman H: Treatment response to bortezomib in multiple myeloma correlates with plasma hepatocyte growth factor concentration and bone marrow thrombospondin concentration. Eur J Haematol 2010, 84:332-336.

32. Pour L, Svachova H, Adam Z, Mikulkova Z, Buresova L, Kovarova L, Buchler T, Penka M, Vorlicek J, Hajek R: Pretreatment hepatocyte growth factor and thrombospondin-1 levels predict response to high-dose chemotherapy for multiple myeloma. Neoplasma 2010, 57:29-34.

33. Teofili L, Di Febo AL, Pierconti F, Maggiano N, Bendandi M, Rutella S, Cingolani A, Di Renzo N, Musto P, Pileri S, Leone G, Larocca LM: Expression of the c-met proto-oncogene and its ligand, hepatocyte growth factor, in Hodgkin disease. Blood 2001, 97:1063-9.

34. Mahtouk K, Tjin EP, Spaargaren M, Pals ST: The HGF/MET pathway as target for the treatment of multiple myeloma and B-cell lymphomas. Biochim Biophys Acta 2010, 1806:208-219.

35. Wang X, Le P, Liang C, Chan J, Kiewlich D, Miller T, Harris D, Sun L, Rice A, Vasile S, Blake RA, Howlett AR, Patel N, McMahon G, Lipson KE: Potent and selective inhibitors of the Met [hepatocyte growth factor/scatter factor (HGF/SF) receptor] tyrosine kinase block HGF/SF-induced tumor cell growth and invasion. Mol Cancer Ther 2003, 2:1085-1092.

36. Rodig SJ, Shapiro GI: Crizotinib, a small-molecule dual inhibitor of the cMet and ALK receptor tyrosine kinases. Curr Opin Investig Drugs 2010, 11:1477-1490.

doi:10.1186/1746-1596-8-16

Cite this article as: Huang and Chuang: High MET gene copy number predicted poor prognosis in primary intestinal diffuse large B-cell lymphoma. Diagnostic Pathology 2013 8:16.

\section{Submit your next manuscript to BioMed Central and take full advantage of:}

- Convenient online submission

- Thorough peer review

- No space constraints or color figure charges

- Immediate publication on acceptance

- Inclusion in PubMed, CAS, Scopus and Google Scholar

- Research which is freely available for redistribution

Submit your manuscript at www.biomedcentral.com/submit
() Biomed Central 